\title{
Inhibition by Exogenous Interferon of Replication of Poliovirus Ribonucleic Acid in Chick Brain
}

\author{
JULIUS S. YOUNGNER AND MARION E. KELLY \\ Department of Microbiology, School of Medicine, University of Pittsburgh, Pittsburgh, Pennsylvania
}

Received for publication 22 April 1965

\begin{abstract}
Youngner, Julius S. (University of Pittsburgh, Pittsburgh, Pa.), and Marion E. KELLY. Inhibition by exogenous interferon of replication of poliovirus ribonucleic acid in chick brain. J. Bacteriol. $90: 443-445$. 1965.-The replication of poliovirus was studied after the intracerebral inoculation of infectious ribonucleic acid (RNA) into the brains of 2-day-old chicks; these animals are not susceptible to intact virus. Single-cycle replication of virus, which reached a peak in about $12 \mathrm{hr}$, was completely inhibited by prior intraperitoneal injection of interferon prepared from the allantoic fluid of chick embryos infected with influenza virus. A single dose of as little as 500 units of interferon, measured by a plaque-reduction method, completely suppressed viral replication when injected $24 \mathrm{hr}$ prior to infectious RNA. This system provides a model for the study of the protection of target organs by passively transferred interferon injected at a distance.
\end{abstract}

The production of poliovirus in naturally resistant animals injected intracerebrally with ribonucleic acid (RNA) prepared from this agent was reported first by Holland, McLaren, and Syverton (1959). Infection of chick embryos with RNA from poliovirus also has been described (Mountain and Alexander, 1959; De Somer, Prinzie, and Schonne, 1959). Hermodsson and Philipson (1963) showed that the inhibition of virus yield in calf kidney cell cultures infected with poliovirus RNA can be used as a sensitive method for assay of interferon.

In the present study, the chick, an animal naturally insusceptible to poliovirus infection, was utilized to determine both the rate of formation of complete poliovirus after intracerebral inoculation of RNA and the effect of exogenous interferon, injected intraperitoneally, on viral replication.

\section{Materials and Methods}

Interferon. Preparation of interferon in chick embryos was done with the WS strain of influenza virus according to the method of Wagner (1961). Embryonated eggs (10 days old) were inoculated into the allantoic cavity with about $10^{4}$ EID $_{50}$ of virus. After incubation for $72 \mathrm{hr}$ at $36 \mathrm{C}$, the allantoic fluids were harvested, pooled, clarified by centrifugation at $500 \times g$ for $20 \mathrm{~min}$, and stored at $-60 \mathrm{C}$. Before use, the infected allantoic fluid was heated at $60 \mathrm{C}$ for $1 \mathrm{hr}$ to destroy the virus. The viral inhibitor was heat-stable, nonsedimentable at $100,000 \times g$ for $2 \mathrm{hr}$, resistant to inactivation at $p \mathrm{H} 2$ for $24 \mathrm{hr}$, trypsin-sensitive, effective in chick cells but not in mouse cells, and did not neutralize vesicular stomatitis virus (VSV), the test virus in the assay for interferon activity. These properties are compatible with those of chick-embryo interferon reported by others (Lampson et al., 1963).

Assay. Interferon assay was performed by use of a plaque-reduction method (Wagner, 1961) in primary chick-embryo cultures, as described previously (Youngner and Stinebring, 1964). Interferon units per milliliter of allantoic fluid were expressed as the reciprocal of the dilution which reduced the VSV plaque count to $50 \%$ of that of the controls.

$R N A$. Infectious RNA was prepared from the Mahoney strain of type 1 poliovirus by use of cold phenol extraction (Holland et al., 1960).

Intracerebral injections of $0.05 \mathrm{ml}$ of RNA in 1 M $\mathrm{NaCl}$ were made into 2-day-old white Leghorn chicks which were kept in an electrically heated brooder before and after inoculation. At different times after inoculation, the chick brains were removed and ground in an all glass homogenizer; $10 \%$ brain suspensions were prepared with trisphosphate buffer $(p \mathrm{H} 7.2)$ as diluent and were clarified by use of low speed centrifugation. The brains of at least three chicks were pooled for each determination. It is important to note that repeated tests have failed to show any measurable production of interferon in the brains or in the circulation of chicks injected intracerebrally with infectious RNA.

Intact poliovirus content of the brain suspensions was determined by use of plaque assays in primary monkey kidney cell cultures. 
TABLE 1. Effect of intraperitoneal injection of interferon on replication of poliovirus in 2-day-old chicks inoculated intracerebrally with infectious $R N A$

\begin{tabular}{c|c|c}
\hline \multirow{2}{*}{$\begin{array}{c}\text { Time brains } \\
\text { harvested after } \\
\text { inoculation }\end{array}$} & \multicolumn{2}{|c}{$\begin{array}{c}\text { Avg PFU per braint of chicks } \\
\text { pretreated with }\end{array}$} \\
\cline { 2 - 3 } & $\begin{array}{c}\text { Normal allantoic } \\
\text { fluid }\end{array}$ & $\begin{array}{c}\text { Interferont } \\
(4,000 \text { units })\end{array}$ \\
\hline$h r$ & & \\
0 & 0 & 0 \\
4 & 0 & 0 \\
6 & $6.4 \times 10^{1}$ & 0 \\
8 & $4.0 \times 10^{2}$ & 0 \\
10 & $2.4 \times 10^{2}$ & 0 \\
12 & $1.2 \times 10^{3}$ & 0 \\
24 & $1.9 \times 10^{1}$ & 0 \\
\hline
\end{tabular}

* Inoculum: $7.2 \times 10^{3} \mathrm{PFU}$ of RNA per brain. $\dagger$ Three chicks per determination.

$\ddagger$ A 2,000-unit amount of interferon in $2.0 \mathrm{ml}$ was injected intraperitoneally $24 \mathrm{hr}$ prior to RNA; 2,000 units were injected at the same time as RNA.

TABLE 2. Influence of amount of interferon inoculated intraperitoneally on inhibition of poliovirus replication in chicks inoculated intracerebrally with infectious $R N A$

\begin{tabular}{c|c|c}
\hline $\begin{array}{c}\text { Amt of interferon } \\
\text { injected 24 hr prior } \\
\text { to RNA }\end{array}$ & $\begin{array}{c}\text { Avg PFU per brain } \\
\text { at 12 hrt }\end{array}$ & $\begin{array}{c}\text { Per cent } \\
\text { inhibition }\end{array}$ \\
\hline Control $\ddagger$ & $4.9 \times 10^{2}$ & - \\
2,000 & 0 & 100 \\
500 & 0 & 100 \\
125 & $1.7 \times 10^{2}$ & 65 \\
31 & $2.3 \times 10^{2}$ & 53 \\
\hline
\end{tabular}

* Inoculum: $3.0 \times 10^{2} \mathrm{PFU}$ of RNA per brain. † Three chicks per determination.

$\ddagger$ Normal allantoic fluid.

\section{RESUlts}

Preliminary studies were made of the appearance of complete poliovirus after the injection of infectious RNA into the brains of chicks. The results showed that plaque-forming units (PFU) resistant to ribonuclease and neutralizable by type 1 poliovirus antiserum appeared in the brains between 4 and $6 \mathrm{hr}$ after injection and reached peak levels at 10 to $12 \mathrm{hr}$.

To test the influence of exogenous interferon given intraperitoneally on the appearance of intact poliovirus after RNA injection, the following experiment was carried out. Groups of 2-day-old chicks were injected intraperitoneally with either normal allantoic fluid (heated at $60 \mathrm{C}$ for $1 \mathrm{hr}$ ) or interferon (allantoic fluid infected with WS virus and heated as described above). Two doses (2.0 $\mathrm{ml}$ ) of normal or interferon-containing allantoic fluid were injected $24 \mathrm{hr}$ apart; a total of 4,000 units of interferon were given to each chick. Immediately after the second dose of control allantoic fluid or interferon, $7.2 \times 10^{3} \mathrm{PFU}$ of Mahoney virus $\mathrm{RNA}$ in $1 \mathrm{M} \mathrm{NaCl}$ were injected intracerebrally into both groups of chicks. At different times after the injection of RNA, three chicks from each group were sacrificed; brains were removed, processed as described above, and assayed for plaque formation in monkey kidney cell cultures (Table 1). In chicks pretreated with normal allantoic fluid, intact poliovirus appeared in the brain $6 \mathrm{hr}$ after RNA injection and reached a peak titer of $1.2 \times 10^{3} \mathrm{PFU}$ per brain at $12 \mathrm{hr}$. In chicks pretreated with interferon, the replication of poliovirus RNA was completely suppressed.

The influence of the amount of exogenous interferon injected on the replication of poliovirus RNA in chick brain was studied as follows. A single injection of heated, infected allantoic fluid, diluted to contain different amounts of interferon, was given intraperitoneally $24 \mathrm{hr}$ prior to the intracerebral inoculation of Mahoney RNA. Control animals were given a single dose of heated, normal allantoic fluid. Brains were harvested 12 $\mathrm{hr}$ after RNA injection, and tissue suspensions were assayed for infective poliovirus by use of the plaque technique. RNA replication was completely inhibited by as little as $\mathbf{5 0 0}$ units of interferon, and 31 and 125 units produced a 53 and $65 \%$ inhibition of virus yield, respectively (Table 2 ). Under the conditions of the test, only inhibition greater than $50 \%$ was considered significant.

\section{Discussion}

The protective effects of interferon in animals usually have been demonstrated when the inhibitor was inoculated at the same site as the challenge virus (Nagano and Kojima, 1958; Isaacs and Westwood, 1959; Cantell and Tommila, 1960; Andrews, 1961; Scientific Committee on Interferon, 1962). In discussing the question of the antiviral action of circulating interferon, Baron (1964) presented evidence that circulating inhibitor may reach and protect cells in the target organ of the virus in advance of virus spread. Mice injected intravenously with mouse serum containing 2,000 units of interferon were protected against a simultaneous $60 \%$ lethal dose of vesicular stomatitis virus given intracerebrally. Protection was observed when interferon was given $4 \mathrm{hr}$ before or $2 \mathrm{hr}$ after intracerebral challenge with as many as 30 lethal doses of vesicular stomatitis virus. In addition, it was shown that active induction of circulating interferon by the intravenous injection of mice with Newcastle dis- 
ease virus (Baron and Buckler, 1963) was followed by increased protection against vesicular stomatitis and encephalomyocarditis viruses injected intracerebrally. These findings are interpreted to indicate that circulating interferon can be protective against virus as it spreads to target organs and secondary peripheral sites.

Baron also showed that as little as 133 units of mouse-serum interferon given intravenously significantly protected mice from the lethal effects of Germiston virus given intraperitoneally. In this connection, Finter (1964) reported that mice are protected against intraperitoneal injection with encephalomyocarditis and Semliki Forest viruses by prior subcutaneous or intramuscular inoculation of 3,000 to 5,000 units of mouse interferon. These results are in essential agreement with those of Baron and the results in the present report which showed that as little as 500 units of interferon given intraperitoneally completely inhibited poliovirus RNA replication in the brain. The lack of standard interferon preparations and the variation in assay methods make it difficult to compare exactly the amounts of interferon necessary to protect in vivo in the different studies.

The inhibition of replication of poliovirus in the brains of chicks injected intracerebrally with infectious RNA by small amounts of exogenous interferon injected intraperitoneally provides favorable conditions for the evaluation of protection of target organs by passively transferred interferon injected at a distance. It is possible to study only one cycle of viral replication since the chick is not susceptible to intact poliovirus. This procedure, by eliminating the complicating circumstance of local production of interferon by the infecting virus, provides a sensitive tool for the investigation of interferon action in vivo.

\section{ACKNowledgment}

This investigation was supported by Public Health Service grant AI-06264 from the National Institute of Allergy and Infectious Diseases.

\section{Literature Cited}

Andrews, R. D. 1961. Specificity of interferon. Brit. Med. J. 1:1728-1730.

BARON, S. 1964. Interferon and recovery from viral infection. In International Symposium, Non- specific resistance to virus infection. Interferon and viral chemotherapy. Smolenice, Czechoslovakia, September 8-11.

Baron, S., ANd C. E. Buckler. 1963. Circulating interferon in mice after intravenous injection of virus. Science 141:1061-1063.

Cantell, K., and V. Tommila. 1960. Effect of interferon on experimental vaccinia and herpes simplex virus infections in rabbits' eyes. Lancet $2: 682-684$.

De Somer, P., A. Prinzie, and E. Schonne. 1959. Infectivity of poliovirus ribonucleic acid for embryonated eggs and unsusceptible cell lines. Nature 184:652-653.

Finter, N. B. 1964. Protection of mice by interferon against systemic virus infections. Brit. Med. J. 2:981-985.

Hermodsson, S., and L. Philipson. 1963. A sensitive method for interferon assay. Proc. Soc. Exptl. Biol. Med. 114:574-579.

Holland, J. J., L. C. McLaren, and J. T. SyverTON. 1959. Mammalian cell-virus relationship III. Poliovirus production by non-primate cells exposed to poliovirus ribonucleic acid. Proc. Soc. Exptl. Biol. Med. 100:843-845.

Holland, J. J., L. C. McLaren, B. H. Hoyer, AND J. T. Syverton. 1960. Enteroviral ribonucleic acid. II. Biological, physical, and chemical studies. J. Exptl. Med. 112:841-864.

IsaAcs, A., AND M. A. Westwood. 1959. Inhibition by interferon of the growth of vaccinia virus in the rabbit skin. Lancet $2: 324-325$.

Lampson, G. P., A. A. Tytell, M. M. Nemes, and M. R. Hilleman. 1963. Purification and characterization of chick embryo interferon. Proc. Soc. Exptl. Biol. Med. 112:468-478.

Mountain, I. M., and H. E. Alexander. 1959. Infectivity of ribonucleic acid (RNA) from type 1 poliovirus in embryonated egg. Proc. Soc. Exptl. Biol. Med. 101:527-532.

Nagano, Y., and Y. KoJima. 1958. Inhibition de l'infection vaccinale par un facteur liquid dans le tissue infecté par le virus homologue. Compt. Rend. Soc. Biol. 152:1627-1629.

Scientific Committee on Interferon. 1962. Effect of interferon on vaccination in volunteers. Lancet 1:873-875.

WaGNER, R. R. 1961. Biological studies of interferon. I. Suppression of cellular infection with Eastern equine encephalomyelitis virus. Virology 13:323-337.

Youngner, J. S., and W. R. Stinebring. 1964. Interferon production in chickens injected with Brucella abortus. Science 144:1022-1023. 